\title{
Sea-level related molluscan plankton events (Gastropoda, Euthecosomata) during the Rupelian (Early Oligocene) of the North Sea Basin
}

\section{K. Gürs ${ }^{1} \&$ A.W. Janssen ${ }^{2}$}

1 Landesamt für Natur und Umwelt Schleswig-Holstein, Hamburger Chaussee 25, D-24220 Flintbek, Germany. E-mail: kguers@1anu.landsh.de (corresponding author)

2 Nationaal Natuurhistorisch Museum, P.O. Box 9517, 2300 RA Leiden, the Netherlands; currently: 12 Triq tal'Hamrija, Xewkija VCT 110, Gozo, Malta. E-mail: ariewjanssen@waldonet.net.mt

Manuscript received: February 2004; accepted: September 2004

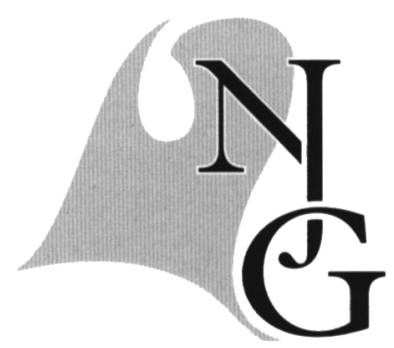

\begin{abstract}
Spacio-temporal distribution patterns of North Sea Basin Early Oligocene (Rupelian) pteropoda (holoplanktonic gastropods: Mollusca, Gastropoda, Euthecosomata) are studied. These patterns indicate three short term invasions of a single pteropod species during the Rupelian. These invasions are indicated here as Clio blinkae Event, Praehyalocylis laxeannulata Event and Clio jacobae Event. The conspicuously short occurrences of the species, their abundances and some lithological features of the pteropod bearing strata lead to the conclusion that these plankton events are linked to sea level high-stands allowing currents from the worlds oceans to enter into the North Sea Basin.
\end{abstract}

Keywords: Pteropoda, Rupelian, Oligocene, North Sea Basin, palaeogeography, biostratigraphy

\section{Introduction}

Pteropoda are a young group of Mollusca, the oldest records dating back not earlier than Late Paleocene (Janssen, 2004). Their pelagic way of life and the fast evolution of many groups make them to excellent biostratigraphic markers. They are also successfully applied in palaeogeography.

In the Early Oligocene pteropod assemblages of the North Sea Basin two superfamilies are distinguished: Limacinoidea and Cavolinioidea (Janssen, 2003). The limacinoids are the most common pteropods in the Cainozoic record of the North Sea Basin. Eight species occur in the Early Oligocene of the North Sea Basin, i.e. Heliconoides dilatata (Koenen 1892), H. hospes (Rolle 1861), H. plana (Tembrock 1964), Limacina acutimarginata (Korobkov 1966), L. conica (Koenen 1892), L. lotschi (Tembrock 1989), L. mariae Janssen 1989 and L. umbilicata (Bornemann 1855). H. plana is recorded from the eastern parts of Germany and western parts of Poland only.

The second group of pteropods, the cavolinioids, are predominantly stenotherm warm water species: most of the Recent species become very rare in higher latitudes. Four species are known from the North Sea Basin Early Oligocene: Creseis cincta (Koenen 1892), Praehyalocylis laxeannulata (Ludwig 1864), Clio blinkae (Janssen 1989) and Clio jacobae (Janssen 1989). All these species have short stratigraphical ranges and some are restricted to very thin levels within the sites. So it was a challenge to differentiate single events, look if they correlate over a long distance and try to give an interpretation for those events.

Additionally, as yet unidentified pteropods are known from the Berg Sand (Janssen \& King 1988), the Kleine Spouwen (Janssen 1979) and Boom Clay (Bosch \& Janssen, 1990) members in Belgium. 


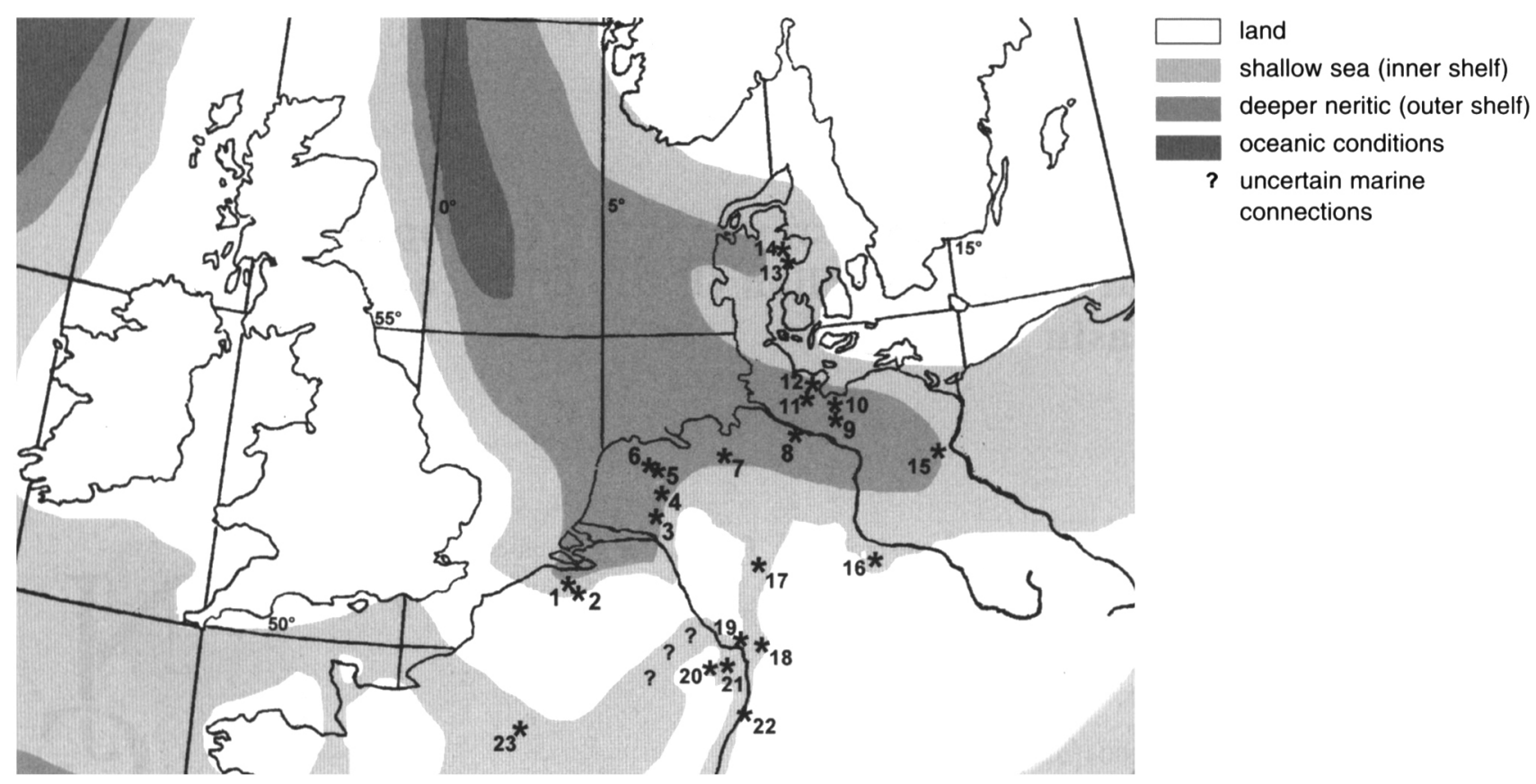

Fig. 1. Pteropod sites and paleogeography during 'Rupel 2' time after Blazchishin, 1991, modified. 1. Rupelian type area, northern Belgium. 2. Grimmertingen, Brabant, B. 3 Winterswijk, Gelderland, NL. 4. Haaksbergen drilling, Overijssel, NL. 5. Ruinerwold, de Wijk-19 drilling, Drenthe, NL. 6. Opende-1 drilling, Groningen, NL. 7. Ankum, Lower Saxony, D. 8. Neuengamme near Hamburg, Lower-Saxony, D. 9. Wienerberger claypit at Malliß, Mecklenburg-Vorpommern, D. 10. Schönberg/Mecklenburg drilling, Mecklenburg-Vorpommern, D. 11. Mönchneversdorf drilling, Schleswig-Holstein, D. 12. Rote Kate drilling, Schleswig-Holstein, D. 13. FIBO clay pit at Ølst, East Jutland, DK. 14. Århus, East Jutland, DK 15. Joachimstal, Mecklenburg-Vorpommern, D. 16. Leipzig Bay, Saxonia, D. 17. Hohenkirchen, Hesse, D. 18. Offenbach, Hesse, D. 19. Wallau, Hesse, D. 20. Alzey, Rheinland-Pfalz, D. 21. Nierstein and Bodenheim, Rheinland-Pfalz, D. 22. Großsachsen near Heidelberg, Baden-Württemberg, D. 23. Morigny, St. Hilaire, Pierrefitte, south of Paris, F.

\section{Material and methods}

The distributional patterns of pteropoda of Early Oligocene borehole sections and outcrops from the North Sea Basin and adjacent areas (Fig. 1) were studied. This study is mainly based on our personal observations over the years, as well as on existing literature. The occurrences of the separate species were dated as exactly as possible.

These data were compared for each of the individual species. The time coherence of the occurrences was checked. The results are discussed below. The following species are discussed here. They will be characterized and illustrated in a forthcoming paper, but reference is made here to illustrations in the existing literature.

\section{Superfamily Limacinoidea \\ Family Limacinidae}

\section{Heliconoides dilatata (Koenen 1892)}

Small species with a conical shell, slightly wider than high, and a subcircular transverse section of the whorls, apertural margin reinforced by a distinct ridge; differing from Heliconoides hospes by its higher shell, differing apertural margin and slower increasing diameter of the whorls (illustration in Koenen, 1892: 994, 995, pl. 62, figs. 3a-b, 4a-c, as Spirialis dilatata).

\section{Heliconoides hospes (Rolle 1861)}

Small species with a low conical shell, distinctly wider than high, circular to subcircular transverse section of the whorls, apertural margin reinforced by a rather suddenly widening of the shell wall (illustration in Janssen, 1984: 63, 69, pl. 2, fig. 1a-d, as Limacina hospes).

\section{Heliconoides plana (Tembrock 1964)}

Small planispiral species with regularly increasing whorls and very slightly concave apical plane, a wide umbilicus and an apertural margin with a distinct ridge; differing from both $L$. lotschi and $L$. mariae by its smaller size and reinforced apertural margin (illustration in Tembrock, 1964: 334, pl. 3. figs.2-3, representing incomplete or juvenile specimens, as Spiratella plana).

\section{Limacina acutimarginata (Korobkov, 1966)}

Medium sized species with an almost convolute, regularly coiled shell, concave apical plane, strongly laterally compressed transverse section of the whorls 
and distinct umbilicus; differing from L. umbilicata by a strong carina on the apical side of the whorls (illustration in Moths, 2000: 40, pl. 13, fig. 9a-b, as Limacina umbilicata).

\section{Limacina conica (Koenen 1892)}

Small species with a high conical, regularly coiled shell, distinctly higher than wide; differing from $H$. hospes and $H$. dilatata by the higher shell and the lack of a reinforced apertural margin (illustration in Koenen, 1892: 994, pl. 62, figs. 5a-b, 6a-b, as Spirialis conica).

\section{Limacina lotschi (Tembrock 1989)}

Small species with a planispiral shell, first whorl wider than the second, otherwise regularly coiled, with a slightly concave apical plane, whorls with laterally compressed transverse section, wide umbilicus; differing from $L$. mariae by the coiling of the first whorls, more compressed transverse section of the whorls and a wider umbilicus (illustration in Janssen, 1989: 107, pl. 3, figs 1-3, pl. 4, fig. 1, as Limacina jessyae Janssen 1989).

\section{Limacina mariae Janssen 1989}

Small species with a planispiral, regularly coiled shell, slightly concave apical plane, laterally compressed transverse section of the whorls and wide umbilicus; differing from $L$. lotschi by a relatively higher shell, narrower umbilicus and faster increasing diameter of the whorls (illustration in Janssen, 1989: 111, pl. 4, figs. 2-5).

\section{Limacina umbilicata (Bornemann 1855)}

Medium sized species (shell height up to $5 \mathrm{~mm}$ ) with an almost convolute, regularly coiled shell, strongly laterally compressed transverse section of the whorls, distinct umbilicus, differing from L. acutimarginata by the regularly curved apical side of the whorls without a carina and a less concave to even slightly convex apical plane (illustration in Bornemann, 1855: 319, pl. 12, fig. 5a-c as Valvatina umbilicata).

\section{Superfamily Cavolinioidea \\ Family Creseidae}

\section{Creseis cincta (Koenen 1892)}

Small to medium sized species with uncoiled, tubiform conical, thin shell, transverse section circular, protoconch elongated bulbiform, differing from Praehyalocylis laxeannulata by its slender shell shape and the lack of distinct transverse ornament. This species, known in insufficient specimens, might belong to the genus Praehyalocylis (illustration in Koenen, 1892: 992, pl. 62, figs. 7a-b, 8a-b).
Praehyalocylis laxeannulata (Ludwig 1864)

Medium sized to large species (height to $20 \mathrm{~mm}$ ) with uncoiled, conical tubiform shell, circular in transverse section, distinct ornament of more or less regular rings and frequently with stepwise increasing shell diameter. Protoconch elongated bulbiform, apical shell part smooth. The nomenclature of this taxon still has to be cleared. Several other names are available (illustration in Moths, 2000: 40, pl. 13, fig. 10).

\section{Family Clioidae}

\section{Clio blinkae Janssen 1989}

Large species (height to $15 \mathrm{~mm}$ ) with uncoiled, conical, dorso-ventrally compressed shell, lateral margins with obtuse carinae, apical shell part strongly bent dorsally, nearly circular in transsection, ventral side of adapical shell portion nearly flat, dorsal side strongly convex with distinct central area, distinguished from C. jacobae by the strongly bent, less slender apical shell part and the strongly convex dorsal side (illustration in Janssen, 1989: 124, pl. 7, figs. 8-14).

\section{Clio jacobae Janssen 1989}

Medium sized species (height to c. $6 \mathrm{~mm}$ ) with uncoiled, conical, dorso-ventrally compressed shell, lateral margins with carinae, lenticular in transverse section, ventral and dorsal sides of adapical shell slightly convex, dorsal part initially with weakly developed central area, fully-grown specimens with three weak ridges, apical shell part more slender and only very slightly curved dorsally (illustration in Moths, 2000: 40, pl. 13, fig. 12a-b).

\section{Results and analyses}

\section{Regional comparison}

\section{Belgium}

The best record of pteropod species is from northern Belgium at or in the vicinity of the Rupelian type area. The Early Oligocene Grimmertingen Sands (NP21, cf. Vandenberghe et al. 2003) yielded Creseis cincta (RGM collection). The Ruisbroek Sands (NP22) contain Limacina mariae. In the Rupelian stratotype sections Clio blinkae occurs exclusively in the so-called 'pink layer' (bed 21 after Vandenberghe 1978), where it can be very abundant. In beds 35 and 36 Praehyalocylis laxeannulata is a common species and within an interval from S41 to S70 (septaria levels) Heliconoides hospes was observed in high numbers. The data on the Boom Clay pteropods are derived from the present authors samples from the Kruibeke-Niel-Rumst-TerhagenHerselt clay pits in the nineteen eighties and ninetees. 
$H$. hospes by the way is absent from higher portions of the Rupelian Boom Clay, but reappears in the basin during the Chattian.

L. umbilicata appears from $S 80$ onwards in the Kruibeke (Bosch \& Janssen, 1990) and Herselt sections and was also recorded (RGM collections) from the upper portions of the Boom Clay in various construction pits of the Antwerpen harbour area.

This shows a clear limitation of pteropods to certain levels (Fig. 2).

\section{The Netherlands}

In the Netherlands Oligocene strata are well documented in borehole sections. In the Ruinerwold, de Wijk-19 borehole at a depth of 305-314 m Limacina lotschi and $L$. dilatata occur. In straigh flush samples from depths of 272-277 m Praehyalocylis laxeannulata, 240-265 m L. umbilicata and 250-255 m Clio jacobae were collected (Janssen \& King 1988). Considering the possibility of downhole contamination by flush drilling these results are very precise, partly due to casing down to a depth of $267 \mathrm{~m}$ (Fig. 3). L. lotschi was also recorded from the Opende-1 borehole (Groningen province) from $510 \mathrm{~m}$ downhole and in sample 515$520 \mathrm{~m}$ together with Creseis cincta and from $520 \mathrm{~m}$ downhole accompanied by L. mariae (Janssen 1989).

The only record of Clio blinkae outside Belgium is from the Haaksbergen borehole (Overijsel province) from 21.95 to $26 \mathrm{~m}$ (Janssen 1989). It is indicated as Ratum Formation but as Janssen (1989) points out it might have been downhole contamination from the overlying Kotten Member of the Brinkheurne Formation which would be time equivalent to the Belgian occurrences.

Janssen \& King (1988) recorded Praehyalocylis laxeannulata also in the Kotten Member of the Brinkheurne Formation of the Winterswijk-Meddo borehole and assert the occurrence of Limacina umbilicata in the Woold Member of the Brinkheurne Formation in the Winterswijk area. In the meantime, however, it has become clear that the assemblage usually indicated as L. umbilicata also contains specimens of $L$. acutimarginata, characterised by the strong carina on the upper part of the whorls. These two forms are found together in the upper Woold Member, but above the boundary with the Winterswijk Member only $L$. acutimarginata remains. Apparently the latter is a further evolutionary stage of L. umbilicata.

\section{Denmark}

Information on Rupelian pteropods from Denmark is scarce but Janssen (1989) mentioned Limacina mariae, L. jessyae $(=$ L. lotschi $)$ and Creseis cincta from the basal part of the Viborg clay of the FIBO clay pit at Ølst

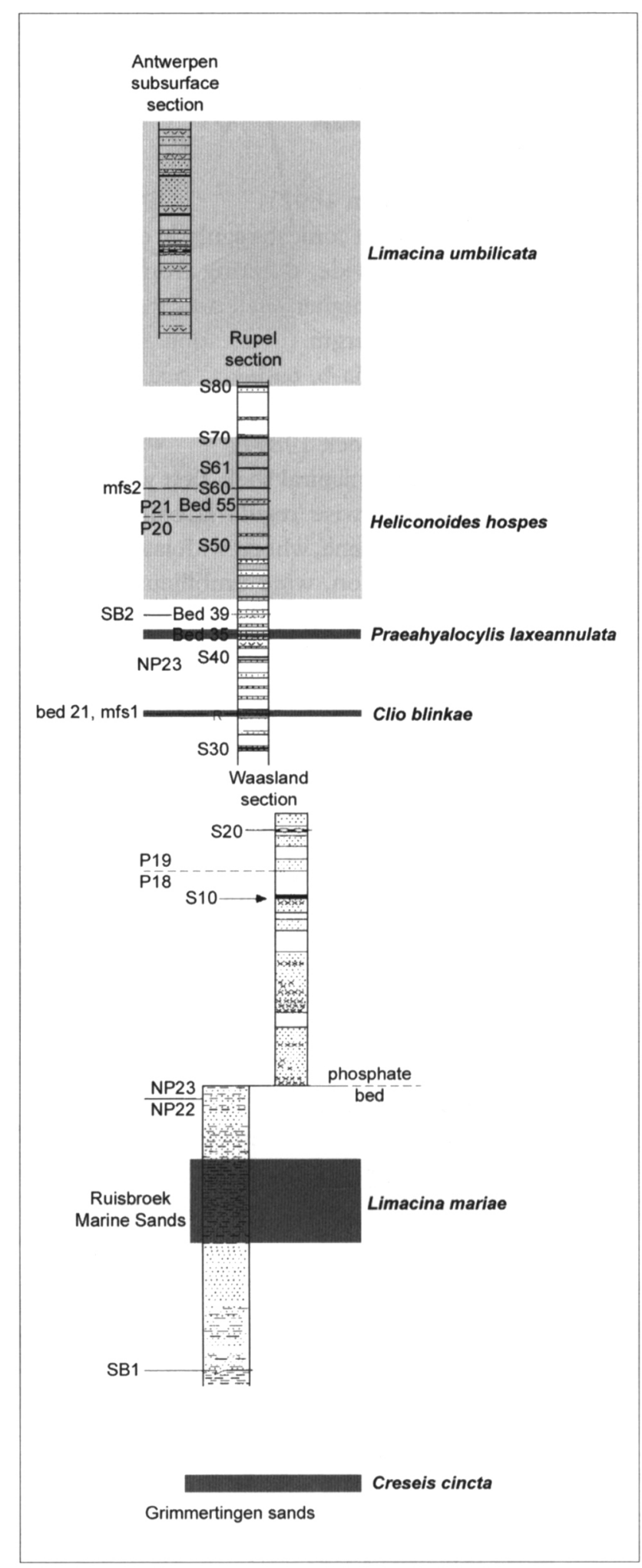

Fig. 2. Pteropod distribution in the Rupelian type area and the Grimmertingen Sands, Belgium (sections from Vandenberghe et al., 1998).

which was dated NP21 to NP22 by Köthe (1988). However, Janssen (1989) doubts the age of NP21 and favours NP22 supported also by accompanying otoliths. Janssen \& King (1988) mention the occurrence of Limacina sp. according to Harder (1913) from 


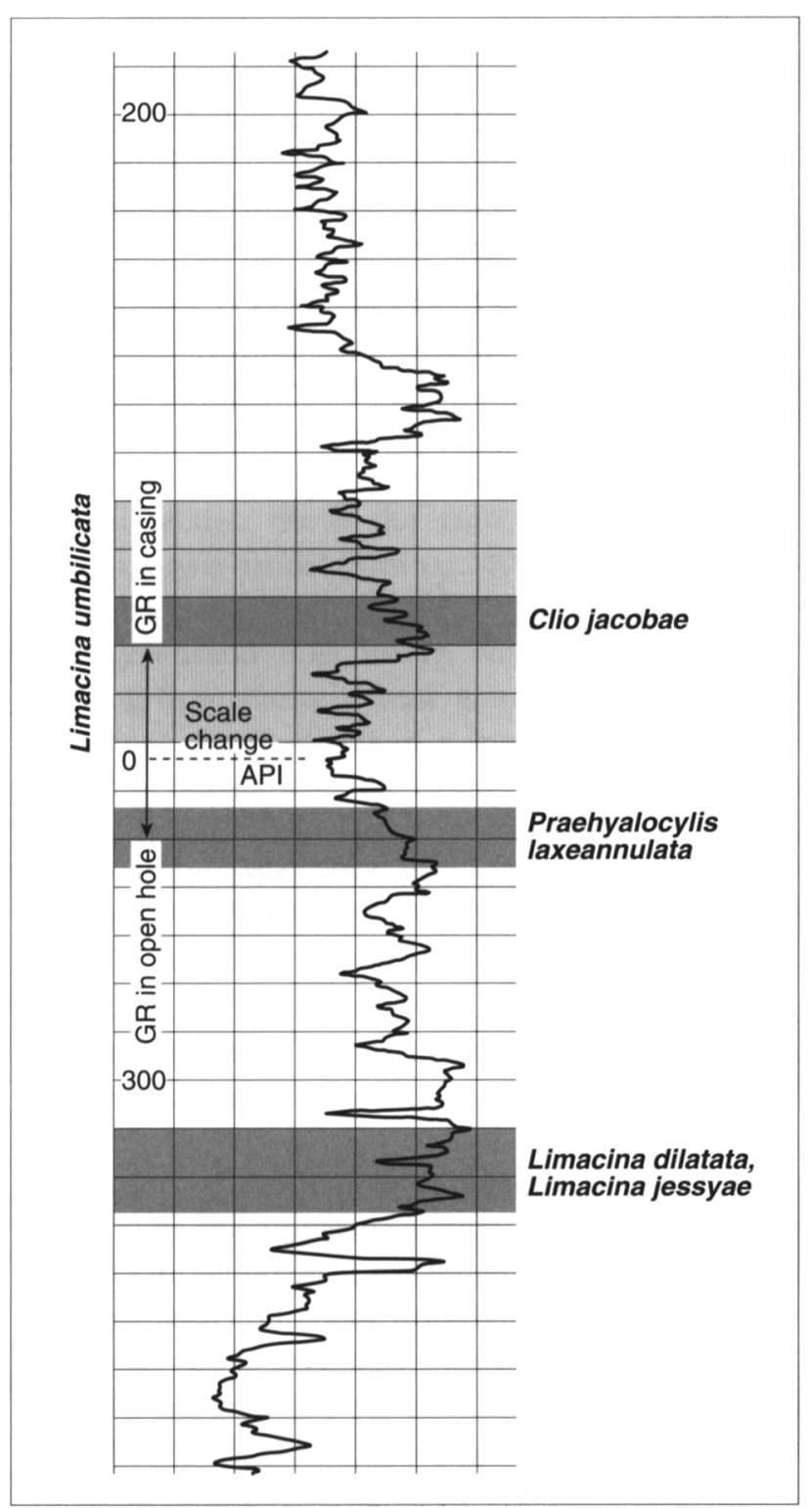

Fig. 3. Pteropod distribution in the Ruinerwold, de Wijk-19 borehole, represented by gamma-log (measured in casing to $267 \mathrm{~m}$, further down in open hole: scale spreading from 10 api to 15 api per scaleline).

the Aarhus railway cutting section, which probably is L. umbilicata. The accompanying benthic molluscan fauna suggests a correlation to the German 'Rupel 4'.

\section{Northern Germany}

Koenen (1892) described Creseis cincta, Limacina conica and $L$. dilatata from the Latdorf deposits. These deposits have to be attributed to NP21 (Martini \& Ritzkowski 1968) and belong to the earliest Oligocene (Gürs, 2004). L. mariae was recently encountered in the Rote Kate well in southern Holstein together with a mixed foraminiferal assemblage of Middle Eocene and Early Oligocene age. The obviously tectonically disturbed sequence on the other hand did not yield further Oligocene pteropods.
The Rupelian Septaria clay is subdivided after Spiegler (1966) into four zones, two of which are empoverished (Rupel 1,3) and two are rich in fauna (Rupel $2,4)$. Rupel 2 yields nannoplankton assemblages of NP23, whereas Rupel 4 contains those of NP24.

Koert (1913) detected Praehyalocylis laxeannulata in the Neuengamme borehole in the basal part of the 'Middle' Oligocene (Rupel 2 according to benthic mollusc fauna) and in the Kirchwerder and Breetze boreholes. He also reported Limacina umbilicata from younger strata of these sections but as they were drilled with the straight flush method the exact depth can not be determined. Hinsch (1977) (unpublished report) found Praehyalocylis laxeannulata in the Mönchneversdorf borehole (318-321 $\mathrm{m}$ ) in sediments of Rupel 2. Gürs (1996) (unpublished report) recognised common Limacina umbilicata in the Schönberg Hy Dep. Soeb 1E3/95 well from Mecklenburg in Rupel 4 sediments (293-304m). Moths (2000) investigated the molluscan fauna of the Malliß clay pit where he found abundant $P$. laxeannulata only in two small layers in Rupel 2 deposits which were significant by their brownish colour in the otherwise greyish green septaria clay. Rupel 4 strata of this locality yielded $L$. umbilicata, L. acutimarginata and Clio jacobae. According to Moths (2000) L. umbilicata partly was so abundant that pyrite concretions were built of thousands of Limacina shells.

A further occurrence of Limacina umbilicata was recorded by Langer (1964) from Ankum near Oldenburg, Lower Saxony, together with a microfauna of Rupel 4. His Creseis sp. might be 'Creseis' berthae?

'Tentaculites maximus' of Boekschoten (1969) from theVaale drilling is not the same as 'Tentaculites maximus Ludwig 1864' (= Praehyalocylis laxeannulata) but belongs also to 'Creseis' berthae Janssen 1989, which is probably not a pteropod.

In the Leipzig area Müller (1983) found Praehyalocylis laxeannulata in the so called 'Zwenkauer Basissand'. It correlates to the Rupel 2 judging from the accompanying benthic molluscan fauna.

Limacina umbilicata is furthermore known from the Hermsdorf, Joachimstal and Freienwalde clay pits of 'Rupel 4'-clay (Janssen \& King, 1988).

In northern Hesse at the southern border of the North Sea Basin Praehyalocylis laxeannulata was reported from the Septaria Clay of Hohenkirchen by Blanckenhorn (1889). In the collection of the Senckenberg Museum, Frankfurt am Main, a sample of three specimens of Praehyalocylis laxeannulata from the Gudensberg 6 borehole (61-64 m), near Kassel is stored. Various specimens are in the RGM collections from the borehole Baatz 6 from 1961 (depth 6.3-7.3 m) at Niederkaufungen (don. E. Kuster-Wendenburg, 1979). 


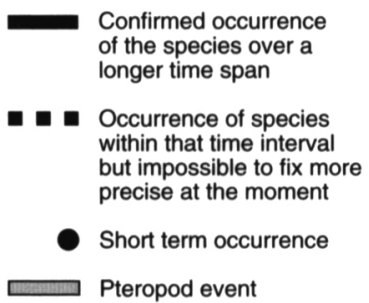

\section{Mainz Basin and Upper Rhine Graben}

In the Mainz Basin Praehyalocylis laxeannulata is known from two thin layers within the Bodenheim Formation, i.e. 'Mittlerer Rupelton' or 'Fischschiefer' of NP23, where it is very abundant, as well as in time equivalent marine sands of the Alzey Formation (KusterWendenburg, 1971). A sample with many specimens of this species is in the RGM collections from the Alzey Formation ('Unterer Meeressand') of Eckelsheim (leg./don. M.C. Cadée). Kuster-Wendenburg (1971) also demonstrated that there are just two horizons in the Alzey Formation containing the species. The types of this species from Ludwig (1864) come from Nierstein, close to Bodenheim. Slabs of laminated clay from the 'Fischschiefer' of Bodenheim from the Kuster-Wendenburg collection at Mainz University and in the Senckenberg Museum at Frankfurt am Main show numerous specimens, sometimes all oriented in the same direction, indicating weak currents (Fig. 5). Further records of this species come from the 'Meeressand' of Großsachsen in the Upper Rhine Graben (Futterer 1892), from the 'Rupelton' of Offenbach east of Frankfurt (Zinndorf 1909, 1928), and from marine sands of Wallau west of Frankfurt (Spandel 1909). Limacina umbilicata occurs rarely in the 'Oberer Rupelton' (NP24) Janssen \& King, 1988).

\section{Paris Basin}

There are finds of a certainly undescribed Clio (?) sp. from the Stampien Inférieur of Morigny and Ormoy-laRivière (Le Renard collection) and some Praehyalocylis laxeannulata from St. Hilaire (RGM collection) and Pierrefitte (Gürs collection) both Stampien Supérieur.

\section{Stratigraphic correlation}

As shown in the regional comparison all investigated regions show the same succession of pteropod species. As far as the stratigraphic resolution allows the occurrences of all pteropod species correlate between the separate regions. So far not all pteropod species could be detected in every region. This seems to be due to the extremely short stratigraphical range of certain

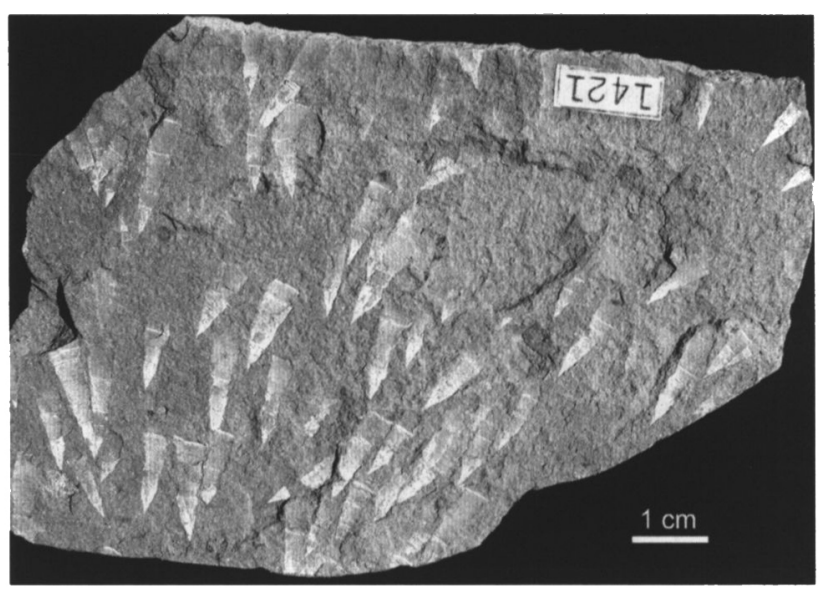

Fig. 5. Praehyalocylis laxeannulata (Ludwig, 1864). Bodenheim near Mainz (Germany). Coll. H. Neuenhaus (1421) ex. Th. Crecelius, Senckenberg Museum, Frankfurt am Main (SMF 327481). Sediment slab of clay from the so-called 'Fischschiefer' (Rupelian, NP 23), showing the abundance of the species. Note the orientation of the specimens indicating weak bottom currents. 
species. Clio blinkae has a mass occurrence in only one thin layer in the Boom Clay, but could only be observed in one borehole section outside this area so far.

A different case is Praehyalocylis laxeannulata. It is restricted to a short interval but observed all over the basin and in the adjacent areas. Already KusterWendenburg (1971) mentioned the high stratigraphic value of this species occurring in the Mainz Basin in two small layers of the 'Rupelton' only. This is true also for the Rupelian type area, where it is only found in beds 35 and 36 of Vandenberghe (1978). The Malliß clay pit section shows the same feature, where the 'Praehyalocylis-bands' (Moths, 2000) are a well-known reference level of the 'Rupel 2' clay ca. $10 \mathrm{~m}$ above the basal greensand. The brown colour of these levels differing from the otherwise greenish gray sediment underlines the character of a special event. Also the 'Zwenkau Basissand' of the Leipzig area (Müller, 1983) with its Praehyalocylis can be correlated with the Rupel 2 of Spiegler (1966) by means of benthic molluscs. Grimm (1994) correlated the Foraminifera Marl and parts of the 'Fischschiefer' of the Bodenheim Formation of the Mainz Basin with the 'Rupel 2' and Grimm \& Steurbaut (2001) correlated the 'Fischschiefer A2', where Praehyalocylis is found, with that part of the Belgian type section that contains this species. Their correlation of the 'Upper Rupel clay' of the Mainz Basin with the uppermost part of the Boom Clay Formation (not actually exposed in the type area) matches perfectly with the common occurrence of Limacina umbilicata. Gürs (1995) correlated the 'Unterer Meeressand' (Alzey Formation) equivalents of the 'Fischschiefer' with the Stampien Supérieur by means of benthic molluscs which fits the common occurrence of Praehyalocylis. The synchronism of the occurrences of the other pteropod species can be demonstrated by their correlation to the nannoplankton stratigraphy and their succession in the studied sections.

\section{Correlation with other planktonic events}

Lund (2002) showed that there is a very unique event detectable all over the North Sea Basin which is the invasion of the dinoflagellate cyst Pseudospiniferites manumii Lund 2002. This is a warm water species with a predecessor in the tropical tethyan Late Cretaceous. It is therefore seen as an immigrated form 'during a period with favourable conditions (sea-level highstands and ? warmer temperatures)' (Lund, 2002: 86). It was observed in the Rupelian type area in the RumstTerhagen section (bed 20 to 26) and in the Kruibeke section (bed 22 to 26). Unfortunately Lund (2002) had no samples of bed 21 with the pink layer but as
P. manumii occurred above and below bed 21 the Clio blinkae level falls within this interval.

Hooyberghs (1983) gave a detailed study on planktonic Foraminifera of the Boom Clay and other Oligocene deposits of Belgium. He found a very close succession of these Foraminifera allowing to recognise Blow Zones P18 to P21. Hooyberghs \& Moorkens (1988) distinguished four Boom Clay faunulas, faunulas 1,2 , and 4 characterized by the new appearances of species. Nevertheless there are no such outstanding events in planktonic Foraminifera as there are in pteropods.

Nannoplankton is abundant in most of the Early Oligocene sediments but there are no important events described in literature. Sphenolithus as warm water form is missing in the North Sea Basin sediments of NP 23 but is present in some levels in the Rheintal Graben sediments of NP 23 (Müller, 1988). Sphenolithus distinctus is detected in NP 24 of Belgium and the Lower Rhine Embayment (Müller \& Köthe, 1988). Unfortunately no further information is given on these occurrences especially if they are bound to distinct layers or if $S$. distinctus is present in the whole interval.

\section{Results}

From the regional comparison a distribution pattern can be drawn (Fig. 4). In NP 21 Limacina dilatata, L. conica and Creseis cincta occurred in the basin. In sediments of NP 22 the same species without $L$. conica but accompanied by $L$. mariae and $L$. lotschi can be observed. In the early part of NP 23 two monospecific pteropod pulses can be seen, first the mass occurrence of Clio blinkae in one level, second the mass occurrence of Praehyalocylis laxeannulata in a very short interval. In the sediments of the upper part of NP 23 Heliconoides hospes is present. Sediments of NP 24 are characterized by L. umbilicata which is common to abundant anywhere in the basin. Within this zone Clio jacobae invades the basin for a short period. Possibly the species $L$. acutimarginata developed from $L$. umbilicata, characterising the uppermost part of NP 24.

\section{Discussion}

The results show that temporal pteropod distribution patterns coincide all over the North Sea Basin and its adjacent areas. That does not necessarily mean that every first observation date of a pteropod species marks an immigration event. Especially Heliconoides dilatata and $H$. hospes might represent an evolutionary lineage, as already supposed by Janssen (1989).

On the other hand Limacina lotschi was recently collected by D. Ward (RGM collection) at Mangyshlak 
(Kazakhstan) from the Adaj Formation (Priabonian). This is the first record from outside the North Sea Basin. It points to an eastern Paratethys connection. Surprisingly L. lotschi is not found in the North Sea Basin before NP22. This may be due to a late invasion of this species or to gaps in our knowledge. L. lotschi may be a successor of a high spired Eocene form showing parallel evolution to the Middle to Late Miocene Limacina valvatina $-L$. ingridae $-L$. wilhelminae - L. atlanta lineage (Gürs \& Janssen, 2002).

In this case it would be a matter of discussion if the members of this lineage die out in the basin and return from outside under favourable conditions or if they stay in the basin but are rare under unfavourable conditions and bloom under improving conditions.

Nevertheless there are five species that presumably have no predecessors in the basin which are Limacina umbilicata, Creseis cincta, Praehyalocylis laxeannulata, Clio blinkae and Cl. jacobae. They immigrate into the basin under favourable conditions. For two of them (Cl. blinkae and Cl. jacobae) a short termed invasion is likely, for P. laxeannulata it is proved. Only C. cincta and $L$. umbilicata and its successor species $L$. acutimarginata survived in the basin for a longer period.

The scanty record of Creseis cincta makes it impossible to decide whether or not the immigration of this species into the North Sea Basin is a remarkable event. Also its long stratigraphical range from NP21 to NP22 is difficult to interpret. It might stand for adequate environmental conditions in the basin as well as an open connection to the worlds oceans during that time or more than one immigration phase of the same species.

Very different is the case of Clio blinkae. This species is found in one bed of max. $5 \mathrm{~cm}$ thickness (Janssen, 1989) but in all outcrops in the Rupelian type area. It always has a mass occurrence. Although the species is found outside Belgium in only one borehole in the Netherlands (probably in the same stratigraphical position) this event is of high palaeogeographical importance. It is in common belief linked to an invasion at a sea level high-stand. Janssen (1989) favours a marine corridor to the Atlantic, but looking at the paleogeography an immigration from the Eastern Paratethys is also possible. It is not very astonishing that $C$. blinkae is so far not found in more eastern parts of the basin as there often is a hiatus covering this time interval.

The most striking event of the pteropod record is the occurrence of Praehyalocylis laxeannulata. It appeared simultaneously and abundantly in Belgium, the Netherlands, Northern Germany, Eastern Germany, the Mainz Basin and the Paris Basin. Only two levels close to one another can be observed in the sections and afterwards the species vanished as suddenly as it came in. The fauna of the marine sandy deposits of the Stampien Supérieur suggests a transgression into the Paris Basin from the south west and a possible connection to the Mainz Basin (Gürs 1995). The 'Fischschiefer' equivalent sandy deposits of the Alzey Formation, containing Praehyalocylis, indicate a very high sea level (Gürs 1995). The brown colour of the Praehyalocylis beds of Malliß and the increase of benthic taxa in these beds show a good oxygene supply of the bottom waters of these bathyal environments (Gürs \& Moths, 2002). A similar change in sedimentation in the bathyal Early Eocene clays of Denmark was interpreted as change in water currents due to sea level rise and establishment of an open water exchange with the worlds oceans (Schmitz et al. 1996). Sections in the Rupelian type area on the other hand show no extraordinary sedimentation patterns in the beds with Praehyalocylis. This can be explained by the fact that this area is much closer to the coast and therefore much more influenced by changes in sediment supply, climate (weathering, humidity) or regional tectonics than the northern German Septaria Clay of Malliß.

Limacina umbilicata appears in NP24 and demonstrates an open marine connection to the eastern Paratethys, from where it and its successor $L$. acutimarginata were also reported (Korobkov 1966, Janssen \& King 1988). The latter inhabited the basin nearly until the end of the Rupelian. Therefore it is a good index fossil for the Late Rupelian or 'Rupel 4'. The 'Rupel 4' as well as the 'Oberer Rupelton' of the Mainz Basin show a very strong trend which suggests that the connection to the Eastern Paratethys established almost certainly due to a eustatic sea level rise.

Within the Limacina umbilicata time interval Clio jacobae is recognised both in the Ruinerwold well and in the Malliß clay pit. It seems to occur only during a short time in the middle of this interval. Although the exact position of the finds of C. jacobae in the Malliß section is unknown Moths (2000) states that he collected the specimens in the uppermost part of the clay exposed at that time, which was well above the first occurrence of $L$. umbilicata. Disregarding the rarity of C. jacobae it is very likely that its occurrence marks one small time interval.

These short term invasions of cavolinioid pteropods have only two possible explanations. The first is a temporary connection of the North Sea Basin to the worlds oceans due to local or regional tectonics at the basin margin in a relatively warm period. The second is a more widely spaced connection during a strong sea level rise allowing warm water currents to enter the basin. The second interpretation is most likely for all three events. The Clio blinkae level was already interpreted as maximum flooding surface by 
sedimentological means (Vandenberghe et al. 2003). The Praehyalocylis laxeannulata beds originated during a strong transgression in the Paris Basin, the Mainz Basin and the eastern margins of the North Sea Basin. Sedimentological features of this level in the Malliß section, which was close to the basin centre of this time, show characteristics indicating a change in the hydrodynamic regime. Although they are not reflected in the more marginal sections of the Rupelian type area they indicate a strong sea level rise.

The Clio jacobae event correlates with a separate cycle in the North Sea Basin (Lintfort Formation, Woold Member of Brinkheurne Formation, Rupel 4, 'Muschelschluff' of the Leipzig area) and Mainz Basin ('Oberer Rupelton'). This makes a eustatic explanation more likely than a regional tectonical.

\section{Conclusions}

From the Early Oligocene North Sea Basin pteropod species at least three show only very short termed invasions: the Clio blinkae Event, Praehyalocylis laxeannulata Event and Clio jacobae Event. Two of these events are combined with sedimentological features that may be explained by a significant change in palaeoceanography and hydrodynamic regime.

Thus the most likely explanation of the pteropod events is a eustatic sea level rise not only leading to a connection to the warmer worlds oceans but also overstepping a threshold level allowing warm water currents to enter the basin and bring in their plankton freight. These currents may have influenced the hydrodynamic regime of the North Sea Basin at least twice by changing water stratification and supplying oxygen to the bottom water.

Although these are promising starting points much further research has to be done to fully understand immigration patterns of pteropods in the North Sea Basin Oligocene history. Especially the record of Priabonian/Early Rupelian pteropods is very incomplete.

\section{Acknowledgements}

The authors wish to thank Robert Jan van Leeuven (TNO-NITG, Utrecht, the Netherlands) and the Nederlandse Aardolie Maatschappij (Assen, the Netherlands) for permission to use the gamma-log of the Ruinerwold, de Wijk-19 drilling. Dorothee Spiegler (IFM-GEOMAR, Kiel, Germany), Anni Dhondt (Institut royale des Sciences naturelles de Belgique (Brussels, Belgium) and Stefan van Simaeys (University of Leuven, Belgium) critically commented on an earlier version of the manuscript. Martin Cadée
(Leiden, the Netherlands), Elisabeth KusterWendenburg and David Ward (Orpington, England) donated pteropod material to the RGM collection. Ronald Janssen (Senckenberg Museum, Frankfurt am Main, Germany) allowed the loan of pteropod samples in his care. Jos Rietstap improved the figures. Last but not least we are indebted to Jane WellingWolf, (Bay-City Translations, Kiel) who improved the English.

\section{References}

Blazchishin, A.I., 1991. Early-Middle Oligocene, Central Europe. In: Alekseev, M.N. (ed): Palaeogeographic Atlas of the Shelf Regions of Eurasia for the Mesozoic and Cenozoic, vol. 2. The Robertson Group; Geological Institute Academy of Sciences Moscow (Llandudno, UK): Map 11.3b.

Blanckenhorn, M., 1889. Pteropodenreste aus der Oberen Kreide Nord-Syriens und aus dem hessischen Oligocän. Zeitschrift der deutschen geologischen Gesellschaft 41: 593-602.

Boekschoten, G.J., 1969. Fossilführung und Stratigraphie des OligoMiozäns von fünf norddeutschen Bohrungen. Meyniana 19: 1-77.

Bornemann, A., 1855. Die mikroskopische Fauna des Septarienthones von Hermsdorf bei Berlin. Zeitschrift der deutschen geologischen Gesellschaft 7: 307-371.

Bosch, M. van den \& Janssen, A.W., 1990. Application of planktonic gastropods ('Pteropods') in biostratigraphy and interregional correlation of Rupelian deposits in Belgium and the Netherlands. Veröffentlichungen des Übersee-Museums (A) 10: 3-10.

Futterer, K., 1893. Die Tertiärschichten von Großsachsen. Mitteilungen der großherzoglichen badischen geologischen Landes-Anstalst 2: 1-19.

Grimm, K., 1994. Aussagen der Foraminiferenfauna zur stratigraphischen Korrelation, Paläoökologie und Paläogeographie des Mittleren Rupeltons (Fischschiefer/Rupelium/Unteroligozän) im Mainzer Becken, im Oberrheingraben, in der Hessischen Senke und in der Leipziger Bucht. Thesis at the Johannes Gutenberg University (Mainz): 145 pp.+5 pl., sections I-XI, 36 sep. tab.

Grimm, K. \& Steurbaut, E., 2001. Foraminiferal biofacies analysis of the Boom Clay Formation in the Rupel Area (Oligocene, Belgium) and correlation with the Mainz Basin (Germany). Aardkundige Mededelingen 11: 9-20.

Gürs, K., 1995. Revision der marinen Molluskenfauna des Unteren Meeressandes (Oligozän, Rupelium) des Mainzer Beckens. Thesis at the Johannes Gutenberg University (Mainz): $314 \mathrm{pp} .+64 \mathrm{pl}$

Gürs, K., 1996. Paläontologischer Bericht, Bohrung: Hy Dep. Soeb. 1E3/95. Geologisches Landesamt, internal report (Kiel), $67 \mathrm{pp}$.

Gürs, K., 2004. Das Tertiär von Nordwestdeutschland in der Stratigraphischen Tabelle von Deutschland 2002. Newsletters on Stratigraphy 42.

Gürs, K. \& Janssen, A.W., 2002. Revised pteropod biostratigraphy for the Miocene of the North Sea Basin. In: Gürs, K. (ed): Northern European Cenozoic Stratigraphy, Proceedings of the 8th biannual joint meeting of the RCNPS/RCNNS. Landesamt für Natur und Umwelt Schleswig-Holstein (Flintbek): 117-131.

Gürs, K. \& Moths, H., 2002. Neues zu den Rissooidea (Mollusca, Gastropoda) aus dem Rupelium (Oligozän) des Mainzer Beckens und des Nordseebeckens. Courier Forschungs-Institut Senckenberg 237: 255-273. 
Harder, P., 1913. De oligocaene lag i Jaernbanegennemskaeringen ved Aarhus Station. Danmarks Geologiske Undersøgelse, II Raekke 22: 1-140.

Hinsch, W., 1977. Paläontologischer Bericht, Bohrung: Mönchneversdorf. Geologisches Landesamt, internal report (Kiel): 1 p.

Hooyberghs, H.J.F., 1983. Contribution to the study of planktonic Foraminifera in the Belgian Tertiary. Aardkundige Mededelingen 2. 1-131

Hooyberghs, H.J.F. \& Moorkens, T., 1988. 4.2.3.6.3 Planctonic foraminifera. In: Vinken, R. (ed): The Northwest European Tertiary Basin. Geologisches Jahrbuch A 100: 190-198, tab. 92-94.

Janssen, A.W., 1979. Over de molluskenfauna van de Nuculaklei en de relatieve ouderdom van enkele midden-oligocene afzettingen in Belgisch Limburg. Afzettingen van de Werkgroep voor Tertiaire en Kwartaire Geologie 0(1): 10-18.

Janssen, A.W., 1984. Type specimens of pteropod species (Mollusca, Gastropoda) described by Rolle (1861), Reuss (1867) and Kittl (1886), kept in the collection of the Naturhistorisches Museum at Vienna. Mededelingen van de Werkgroep voor Tertiaire en Kwartaire Geologie 21(2): 61-91.

Janssen, A.W., 1989. Some new pteropod species from the North Sea Basin Cainozoic (Mollusca, Gastropoda, Euthecosomata). Mededelingen van de Werkgroep voor Tertiaire en Kwartaire Geologie 26(3): 91-133.

Janssen, A.W., 2003. Notes on the systematics, morphology and biostratigraphy of fossil holoplanktonic Mollusca, 12. Considerations on a subdivision of Thecosomata, with the emphasis on genus group classification of Limacinidae. Cainozoic Research, 2(1-2): 163-170.

Janssen, A.W., 2004. Fossil holoplanktonic Mollusca. Website at http://sites.waldonet.net.mt/ariewe/

Janssen, A.W. \& King, C., 1988. Planktonic molluscs (Pteropods). In: Vinken, R. (ed): The Northwest European Tertiary Basin. Geologisches Jahrbuch A 100: 356-368, tab. 188-204.

Koenen, A. von, 1892. Das Norddeutsche Unter-Oligocän und seine Mollusken-Fauna. Abhandlungen zur geologischen Special-Karte von Preussen und der Thüringischen Staaten 10 (4): 819-1004 + pl. 53-62.

Koert, W., 1913. Geologische und paläontologische Mitteilungen über die Gasbohrung von Neuengamme. Jahrbuch preußische geologische Landesanstalt 32 (1911): 162-182.

Korobkov, I.A., 1966. Krylonogie (Mollusca Pteropoda) Paleogenovykh otlozhenij juga S.S.S.R. Voprosy Paleontologii, 5: 71-92, pls 1-4.

Köthe, A., 1988. Nannoplankton, 4.4.2.7 Denmark. In: Vinken, R. (ed): The Northwest European Tertiary Basin. Geologisches Jahrbuch A 100: 280-283, tab. 139.

Kuster-Wendenburg, E., 1971. Pteropoden-Arten der Gattung Creseis Rang, 1828 aus den mitteloligozänen (Rupelium) Sedimenten des Mainzer Tertiärbeckens. Abhandlungen hessisches Landes-Amt für Bodenforschung 60: 99-112.

Langer, W., 1964. Kurze Bemerkungen zur Mikro und Megafauna des norddeutschen Mitteloligozäns. Neues Jahrbuch für Geologie und Paläontologie, Monatshefte, Abt. B 1964: 730736

Lund, J.J., 2002. A Lower Oligocene Norwegian Sea Dinoflagellate Cyst Found in the North Sea and in the Rupelian Type Area in Belgium. In: Gürs, K. (ed): Northern European Cenozoic Stratigraphy, Proceedings of the 8 th biannual joint meeting of the RCNPS/RCNNS. Landesamt für Natur und Umwelt Schleswig-Holstein (Flintbek): 83-89.
Martini, E. \& Ritzkowski, S., 1968. Was ist das 'Unter-Oligocän'? Nachrichten der Akademie der Wissenschaften zu Göttingen, mathematisch-physikalische Klasse 1968: 231-250.

Moths, H., 2000. Die Molluskenfauna im Rupelton der Ziegeleitongrube Malliß im Wanzeberg (südwestl. MecklenburgVorpommern). Regionalmuseum Malliß (Kaliß): 103 pp.

Müller, A., 1983. Fauna und Palökologie des marinen Mitteloligozäns der Leipziger Tieflandsbucht (Böhlener Schichten). Altenburger Naturwissenschaftliche Forschungen 2: 1-152.

Müller, C., 1988. Nannoplankton, 4.4.2.3 France - the Federal Republik of Germany, the Rhine Graben. In: Vinken, R. (ed): The Northwest European Tertiary Basin. Geologisches Jahrbuch A 100: 266-267, tab. 132.

Müller, C. \& Köthe, A., 1988. Nannoplankton 4.4.1 The description of the interregional zonation (NP zones, NN zones). In: Vinken, R. (ed): The Northwest European Tertiary Basin. Geologisches Jahrbuch A 100: 253-261, tab. 129.

Schmitz, B., Heilmann-Clausen, C., King, C., Steurbaut, E., Andreasson, F.P., Corfield, R.M. \& Cartlidge, J.E., 1996. Stable isotope and biotic evolution in the North Sea during the early Eocene Albaeck Hoved section, Denmark. In: Knox, R.W.O'B., Corfield, R.M. \& Dunay, R.E. (eds) (1996): Correlation of the Early Paleogene in Northwest Europe, Geological Society Special Publications 101: 275-306.

Spandel, E., 1909. Der Rupelton des Mainzer Beckens, seine Abteilungen und deren Foraminiferenfauna, sowie einige weitere geologisch-paläontologische Mitteilungen über das Mainzer Becken. Berichte des Offenbacher Vereins für Naturkunde 4350: $57-230$

Spiegler, D., 1966. Biostratigraphie des Rupels auf Grund von Foraminiferen im nördlichen Deutschland. Geologisches Jahrbuch 82: 447-486.

Vandenberghe, N., 1978. Sedimentology of the Boom Clay (Rupelian) in Belgium. Verhandelingen Koninklijke Academie voor Wetenschappen, Letteren en Schone Kunsten van België, Klasse van de Wetenschappen 147: 137 pp.

Tembrock, M.L., 1964. Einige Beispiele von Faziesabhängigkeit bei tertiären Gastropoden. Berichte der geologischen Gesellschaft in der Deutschen Demokratischen Republik, 9(3): 311-337, pls 3-8.

Vandenberghe, N.; Laga, P.; Steurbaut, E.; Hardenbol, J. \& Vail, P.R., 1998. Tertiary Sequence Stratigraphy at the Southern Border of the North Sea Basin. In: Graciansky, P.-C.; Hardenbol, J.; Jacquin, T. \& Vail P.R. (eds): Mesozoic and Cenozoic Sequence Stratigraphy of European Basins, SEPM Special Publications 60: 119-154.

Vandenberghe, N.; Brinkhuis, H. \& Steurbaut, E., 2003. The Eocene/Oligocene boundary in the North Sea Area: A sequence stratigraphic approach. In: Prothero, D.R.; Ivany, L.C. \& Nesbitt, E.A. (eds): From greenhouse to icehouse. The marine EoceneOligocene transition. Columbia University Press (New York): 419-437.

Zinndorf, J., 1909. Mitteilung über die Tiefbohrung im Städtischen Schlachthofe zu Offenbach a. M. Jahrbuch des Vereins für Naturkunde zu Offenbach 50: 231-236.

Zinndorf, J., 1928. Die Versteinerungen aus den TertiärAblagerungen von Offenbach a. M. Berichte des offenbachschen Vereins für Naturkunde 66-68: 1-65. 